\title{
Onomastics and Branding for Culinary Tourism: Evidence Soto Traditional Culinary
}

\author{
Tri Wiyana ${ }^{1 *}$, IKG Bendesa ${ }^{2}$, Roberto Tomahuw $^{3}$ \\ ${ }^{1}$ Hotel Management Department, Faculty Economics of Communication, Bina Nusantara \\ University \\ ${ }^{2}$ Faculty Economics and Business, Udayana University \\ 3 Administration Management Accounting Department, LEPISI Secretary and Management \\ *triviyana@binus.edu
}

\begin{abstract}
Soto is a traditional culinary dish that is one of Indonesian specialties whose ingredients consist mainly of meat, and vegetable broth. Every region in Indonesia has soto with different characteristics. This study aimed to research the extent to which the naming pattern, the consumer perceives the brand and how much it effects of sales culinary business culinary business in Delanggu District, Klaten Regency, Central Java, Indonesia. Respondents consisted of culinary soto traders and customer perception. Research methodology with qualitative methods by analyzing the naming of the identity of the place of business (onomastic). The next analysis is to integrate branding strategy in developing culinary business. The results of the study showed that the creative branding model for traditional culinary soto, which is how the behavior for making it, the presentation culinary model, and branding with identical names of the people who make it. This research provides an overview of the pattern of branding strategies for culinary endeavors. Culinary entrepreneurs must strive to attract customers with creative models and not ignore local wisdom from the region.
\end{abstract}

Keywords: Traditional Culinary, Culinary Linguistics, Culinary Branding, Soto 


\section{A. Introduction}

The Government of Indonesia (GoI) has a strong commitment to reducing energy elasticity and emission. The development of tourism in global has implications for the high interest of investors to open businesses. Investment does not only occur in the hotel and villa business, but also in restaurants and traditional culinary, given that much of the literature on food tourism defines cuisine as place and is used in many forms and interactions with tourists (Ellis et al., 2018). Many countries are beginning to realize the culinary potential for community welfare and the development of tourist destinations. In the beginning, food only became one of the complementary tourist activities. But then developed a form of special tourism called the term culinary tourism considering food is also recognized as expressive identity and culture. Food experiences connected with memory, and these food experiences and souvenirs may influence destination image and lead to future purchases (Stone, Migacz, \& Wolf, 2018). The Indonesian Minister of Industry said the food and beverage industry contributed $34.33 \%$ of gross domestic product (GDP). The growth of the food and beverage and beverage industry in 2017 reached a level of $9.23 \%$, an increase compared to 2016 of $8.46 \%$ (Yasmin, 2018).

Delanggu is one of the sub-districts in Klaten Regency, Central Java, Indonesia. Delanggu consists of 16 villages, namely: Banaran, Bowan, Butuban, Delanggu, Dukuh, Gatak, Jetis, Karang, Kepanjen, Krecek, Mendak, Sabrang, Segaran, Sidomulyo, Sribit, and Tlobong (BPS-Klaten Regency, 2019). Delanggu is located on the main highway between Yogyakarta and Surakarta, so the economy of this region can grow rapidly. Every region has different culinary specialties, one of the delicacies of Delanggu is Soto. One type of food chosen as an Indonesian culinary icon is Soto, which is called Indonesian soup (Susilaningsih \& Yudistira, 2017). There are several types of soto in Delanggu, each of which has a different way of serving. Soto can be served with a variety of side dishes as a complement. As we know that the staple food of Indonesian people is rice, so soto is usually served with rice as the main menu. Some kinds of superior soup in Delanggu sub-district are as follows:

Table 1 List of Naming culinary Soto in Delanggu

\begin{tabular}{lll}
\hline $\begin{array}{l}\text { Name of Soto } \\
\text { (Branding) }\end{array}$ & Owner & Excellence \\
\hline Gunting (scissors) & $\begin{array}{l}\text { Slamet Widodo, } \\
\text { Mr. }\end{array}$ & $\begin{array}{l}\text { Use scissors for soto; visited by } \\
\text { Mr. President Joko Widodo }\end{array}$ \\
\hline Minthi (duckling) & Bambang, Mr. & Small bowl for soto \\
\hline Sewu (thousand) & Family & Price is very cheap \\
\hline Garing (dry) & Family & Dry, no sauce \\
\hline
\end{tabular}

\section{B. Literature Review}

Scholars argue that food is one of the crucial elements that influence intention to visi (Md. Zain et al., 2018). The culinary resources and culture (e.g., ingredients, 
cooking styles and presentation) are location-specific and can play an important role in destination image formation (Bjork \& Kauppinen-Räisänen, 2016). Tangible elements of local and international foods (e.g., taste and ingredients) can contribute to cognitive and affective elements (e.g., emotions and experiences) of the destination image (Silkes et al., 2013).

Since food is much more than a nutrient, it is one central element of human lives. As for language, it is a primary means for human to transmit meaning. Therefore, the focus on language and its use can explore more aspects of food. Represents a first attempt at delimiting the field of culinary linguistics that are (Gerhardt et al., 2013; Fitrisia et al., 2018):

1. Comparative linguistics

2. Morphology and word formation

3. Syntax and grammar

4. word and meaning

5. spoken discourse

6. food writing

These fields of culinary linguistics can be described as follows. First, every language in this world has their food terminology since eating is a biological necessity. For example, cultures turn on the food items for some reasons such as the endemic plants or historical language contact. Second, the study of morphology and word formation processes deals with the denomination of food items such as compounding, borrowing and eponyms or anthroponym. The words wander around the world together with the food items such as the local food name soto which becomes popular as Indonesian culinary identity. Third, the study of grammatical framework such as construction grammar, cognitive linguistics, pattern grammar or research in corpus linguistics stress the inseparable nature of syntax and lexis (Gerhardt et al., 2013). For example, verbs denote food preparation or ways of eating and nouns represent food items such as dishes or ingredients and kitchen utensils. Fifth, the spoken discourse can study about how offering food to guests includes referring to the food on the table using summonses, demonstratives, gestures, and body practices in Indonesian local culture.

A brand, which is commonly associated with a logo or a name, it represents the personality of the company and its audience (Davis, 2017). We will simply use the term food branding from now on when we mean city or place branding in relation to food, beverages, meals, eating and gastronomy (Berg \& Sevon, 2014), to attention the potential and excellence in the tourism sector that can have a strong identity as a city of culture and tourism (Wiyana et al., 2018). The development and continuation of valuable brands requires a return to those who invest in them (Pearson \& Pearson, 2015). Restaurant branding cannot be done instantly but must be built step by step so the results are maximum, the way consumers perceive attributes of patron dining

Tourism Research Journal, Volume 5 (1), 2021 
behavior (PDE) can conflict with the relationship with the chain restaurants when they commit an unfavorable brand image to memory (Tuan et al., 2018)). The positive effect of brand effect on brand reputation in restaurant industry (Han et al., 2015). Soto culinary has the potential to become a favorite dining place, not only attractive to local resident, but also a main culinary destination for tourists who come to the city of Delanggu.

The difference between this study and previous research is that it focuses on consumer perceptions (quality, opinion, benefit, price and image) on Soto culinary, which is the main culinary destination for tourists who come to the city of Delanggu.

\section{Research Methodology}

This study uses a descriptive qualitative approach. Another important point in qualitative fields, strongly linked with coherence of the writing, concerns the bonds between theoretical and applied dimensions. It is especially important to fully describe the process that converts theory to application, making each step and each link made by the researcher explicit (Crescentini \& Mainardi, 2009). Qualitative research is inductive in nature, and the researcher generally explores meanings and insights in given situation (Corbin \& Strauss, 2008; Mohajan, 2018).

\section{Population and Sample}

Study locations in Delanggu District, Klaten Regency, Central Java Province, Indonesia. The term sample should not refer to an empirical sample as a subset of a population (Manen, 2014). The population of this research is consumers or buyers of soto culinary, both those who have long been old customers and new customers. The samples to be taken are 30 consumers and 4 stall owners. The researcher categorizes the sample above as a nonprobability sample, because this study will use ease-based sampling (available sampling). Through convenience-based sampling techniques, researchers will freely choose consumers that are easily obtained by researchers. In addition to the transcription of the actual interview, the researcher makes advance contact about the interview and who actual the interview, make an observations journal, records the observer's observations and experiences during the interaction.

\section{Instruments}

Asking questions about who, when, where, how, with what consequences, and under what conditions phenomena occur, helps to 'find' important ideas for theory (Corbin \& Strauss, 2008). The instruments used in the naming and branding patterns in the consumer perspective are as follows:

Table 2 List instrument for customer

\begin{tabular}{cl}
\hline Item & Question \\
\hline 1 & Quality: Taste of culinary soto \\
2 & Opinion: Opinion community of culinary soto \\
3 & Benefit: Favorite place of culinary soto \\
4 & Price: Most affordable price of culinary soto
\end{tabular}

Tourism Research Journal, Volume 5 (1), 2021 
5 Image: Unique aspect of culinary soto

\section{Data Analysis}

The analysis technique used is to use qualitative data analysis, meaning that the data obtained in the study will be reported as it is then analyzed descriptively to get a detailed picture of what the researchers encountered during the data collection process.

\section{Results}

Onomastic in culinary, naming strategies monomini and polimini are the most common strategies applied. From the search results, found the names of culinary soto places with samples of four famous soto culinary places as follows:

Table 3 List of monomini and polimini culinary soto

\begin{tabular}{|c|c|}
\hline $\begin{array}{l}\text { Name of Soto } \\
\text { (Branding) }\end{array}$ & Naming pattern \\
\hline Gunting (scissors) & $\begin{array}{l}\text { Javanese with the meaning of the name of the cutting } \\
\text { tool }\end{array}$ \\
\hline Minthi (duckling) & $\begin{array}{l}\text { Javanese with the meaning of the name of a duckling } \\
\text { animal }\end{array}$ \\
\hline Sewu (thousand) & Javanese with the meaning of a thousand \\
\hline Garing (dry) & Javanese with the meaning of an unusual condition \\
\hline
\end{tabular}

Consumers provide product choices to brands based on assessment and experience when using products other than that brand names that are easy to pronounce. Naming that uses a place name, owner's name, or name of the way it is made is often used in business. Description of business activities in the culinary field is a naming device that uses the core business to give the name. The interview results between culinary owners and consumers were examined with the match analysis table as follows:

Table 4 Perception of culinary soto

\begin{tabular}{|c|c|c|c|}
\hline \multicolumn{4}{|c|}{ Linguistics of Culinary Soto } \\
\hline Gunting (scissors) & $\begin{array}{l}\text { Minthi } \\
\text { (duckling) }\end{array}$ & Sewu (thousand) & Garing (dry) \\
\hline Delicious $(43 \%)$ & Delicious $(23 \%)$ & $\begin{array}{l}\text { Delicious } \\
(17 \%)\end{array}$ & $\begin{array}{l}\text { Delicious } \\
(17 \%)\end{array}$ \\
\hline Popular $(40 \%)$ & Popular $(30 \%)$ & Popular $(17 \%)$ & Popular $(13 \%)$ \\
\hline $\begin{array}{l}\text { Convenience } \\
(47 \%)\end{array}$ & $\begin{array}{l}\text { Convenience } \\
(27 \%)\end{array}$ & $\begin{array}{l}\text { Convenience } \\
23 \%)\end{array}$ & $\begin{array}{l}\text { Convenience } \\
(3 \%)\end{array}$ \\
\hline $\begin{array}{l}\text { Affordable } \\
(17 \%)\end{array}$ & $\begin{array}{l}\text { Affordable } \\
(13 \%)\end{array}$ & $\begin{array}{l}\text { Affordable } \\
(37 \%)\end{array}$ & $\begin{array}{l}\text { Affordable } \\
(33 \%)\end{array}$ \\
\hline Authentic $(33 \%)$ & Authentic $(30 \%)$ & $\begin{array}{l}\text { Authentic } \\
(17 \%)\end{array}$ & $\begin{array}{l}\text { Authentic } \\
(20 \%)\end{array}$ \\
\hline
\end{tabular}

Tourism Research Journal, Volume 5 (1), 2021 
In table 4, branding activities in the Soto culinary field were found in the onomastic aspect with five analysis, namely delicious, popular, convenience, cheap, and authentic. Delicious as branding culinary soto. The highest percentage is the dimension of good taste by $43 \%$, the matter of taste is never different (consistent), then what distinguishes it from other soto stalls, here uses thethelan (meat that still sticks to boiled beef bones for soto broth), although the broth is clear, the broth is very pronounced. Sensation of taste has an important role in human life, at the physical, survival, social and even emotional level. Eating and drinking are associated with happiness and positive memories, which emphasizes that aspects of taste should not be ignored by culinary owners. In addition, adding flavor or offering other menus increases the value and benefits that customers feel, which distinguishes brands positively in their minds. However, taste should not be lonely in the branding process because adding this extra dimension will lead to stronger emotional relationships for consumers.

\section{E. Discussion}

\section{Popular as Branding Culinary Soto}

The highest percentage is the dimension of popular by $40 \%$, as already mentioned, the culinary soto gunting has a different ritual meaning, compared to other soto culinary. The way to get greater attention in the eyes of the community, by making slogans that are easy to remember and interesting, a different atmosphere, and impressing the brand of gunting that is already known to the public will certainly gain more trust from the community. So that when they need something that will first occur. Also because of the region's naming of Javanese values and culture, it is very easy to build a brand by utilizing existing local names and cultures. This result adds to culinary research by exploring the effect of food attitudes on behaviours related to local food and local food markets (Bjork \& Kauppinen-Raisanen, 2016).

\section{Convenience as Branding Culinary Soto}

The highest percentage is the dimension of convenience by $47 \%$, for the soto culinary business chain, a consistent and attractive store image package provides the basis for the trend of change. For example, with food service programs, additional side dishes, and specialty drinks, and location access is very easy with the aim of encouraging awareness and sales of certain categories. Another outside element is creating a more comfortable environment, providing a more convenient culinary place to shop. This result particularly interested in the ways in which places are usingthe sensory elements related to food in theirattempts to produce a desirable brand imageof themselves. From contemporary research on branding that brand image concernsnot only the way in which an agent is able toconvey a captivating image of a place, but thatit is also dependent on the way the place isdepicted in popular media, and ultimately howthe image is appropriated by audiences (Berg \& Sevon, 2014). 


\section{Affordable as Branding Culinary Soto}

In terms of price, number of soto culinary places are cheaper compared to the others, the culinary soto Sewu (thousand) is priced at one thousand rupiahs. In other places with the composition of prices of six thousand rupiahs, five thousand rupiahs, and three thousand rupiahs. Affordable prices and availability of Soto culinary. In the process of forming a perception of this, consumers will compare the prices listed or listed with prices thought. From the results of this comparison is formed perceptions that will direct consumers to choose Soto culinary at the lowest price, this is because psychologically, humans will apply economic principles in their lives, where in the economic principles of every human effort will be based on the best and most profitable choices. The study results illustrate that eating/drinking experience with more elements tends to be more memorable. Another observation is that no elements are needed. On the other hand, the large variety of memorable food/drink experiences (e.g., type of food, price range, location) is notable (Stone, Migacz, \& Wolf, 2018).

\section{Authentic as Branding Culinary Soto}

His famous cuisine is delicious and his expertise in entertaining guests is the main capital to invite customers. The authentic element in this case is the uniqueness of the method of serving soup. Customers will be treated to "scissors" (scissors) in cutting meat. But "scissors" (scissors) are used to cut chicken, meat, and other side dishes, this is one of the most famous and popular among tourists and people who visit the culinary soto gunting (scissors). These generic themes of result include authentic/local foods. A tourism researcher separately read all responses and categorized specific experiences that may be in memory. This expansive list includes the role of food, the meal period, specific beverage, specific foods, setting, service quality, the occasion, and specific city or country (Stone, Migacz, \& Wolf, 2018).

\section{F. Conclusion}

In the aspect of the culinary strategy branding soto how products can be recognized by consumers, there are several results in this study. In the concept of sensory branding, the culinary brand identity "Soto" was created involving sensory stimulation of the five human senses:

Maintaining the consistency of chicken flavor, must maintain maturity, spicy sweetness, and it is very difficult. The taste (food) changes it is something that is understandable because (keeping the taste) is not easy. So now we focus on fast food industry by choosing one menu and we maintain consistency. The property identified from the way of serving soto culinary in its presentation uses scissors "scissors" as additional side cutters and uses a small bowl. This is very synonymous with soto culinary products that are very remembered by consumers. In other words, the brand strategy of soto culinary products can be done because of the unique presentation model.

When people visit a restaurant, the first thing they encounter is a card or board for a culinary business menu. The menu display certainly contains the type and price

Tourism Research Journal, Volume 5 (1), 2021 
of the menu displayed for customers. Customers can choose dishes that fit their pockets after seeing the menu display. The price per menu in "Soto" culinary is an important consideration in choosing consumers to buy "Soto" cuisine. The price variant displayed with the lowest price is one thousand rupiah, so the strategy pattern applied is how to make that price become identical in the minds of consumers. Maintaining the consistency of chicken flavor, must maintain maturity, spicy sweetness, and it is very difficult. The taste (food) changes it is something that is understandable because (keeping the taste) is not easy. So now we focus on fast food industry by choosing one menu and we maintain consistency.

Now is indeed the culinary business season, everyone wants to make a restaurant. Food business is a business that is not easy. Not only can people cook well or just find a chef and then provide a place and can be left behind. Subsequent research in the field of culinary business must have a unique variable. The variable competency of taste from the quality of food products is an important thing in the competitive culinary business.

\section{G. Acknowledgement (optional)}

Authors wish to thank Professor I Komang Gde Bendesa for supporting this research. Support from fellow colleagues also highly appreciated.

\section{REFERENCES}

Md. Zain, N. A., Mohd Zahari, M.S., \& Hanafiah, M. H. (2018). Food and Tourism Destination Image: Moderating Effect of Local Food Consumption. e-Review of Tourism Research (eRTR), 15(1): 21-36.

Berg, P. O, \& Sevon, G. (2014). Food-branding places-A sensory perspective. Place Branding and Public Diplomacy, 10(4): 289-304.

Bjork, P., \& Kauppinen-Raisanen, H., (2016). Local food: A source for destination attraction. International Journal of Contemporary Hospitality Management, 28(1): 177194.

BPS-Klaten Regency. (2019). Kecamatan Delanggu dalam angka. Klaten: BPS-Klaten Regency

Corbin, J. M., \& Strauss, A. L. (2008). Basics of qualitative research: Techniques and procedures for developing grounded theory. Thousand Oaks: CA Sage.

Crescentini, A., \& Mainardi, G., (2009). Metodological Corner Qualitative research articles: guidelines, suggestions and needs. Journal of Workplace Learning, 21(5): 431-439.

Davis, M. (2017). The fundamentals of branding. Bloomsbury Publishing.

Ellis, A., Park, E., Kim, S., \& Yeoman, I. (2018). What is food tourism. Tourism Management, 68: 250-263.

Fitrisia, D., Sibarani, R., Mulyadi., \& Ritonga, M. U. (2018). Traditional food in the percpective of culinary linguistics. International Journal of Multidisciplinary Research and Development. 24-27.

Tourism Research Journal, Volume 5 (1), 2021 
Gerhardt, C, M Frobenius, and S Ley. (2013). Culinary Linguistics; The chef's special. Amsterdam: John Benjamins Publishing Company.

Han, S H, B Nguyen, and T J Lee. 2015. "Consumer-based chain restaurant brand equity, brand reputation, and brand trust. International Journal of Hospitality Management, 5(2): 24-27.

Manen, M. V. (2014). Phenomenology of practice: Meaning-giving methods in phenomenological research and writing. California: Left Coast Press.

Mohajan, H. K. (2018). Qualitative Research Methodology in Social Sciences and Related Subject. Journal of Economic Development, Environment and People, 7(1): 2348.

Pearson, D., \& Pearson, T. (2015). Branding Food Culture: UNESCO Creative Cities of Gastronomy. Journal of Food Products Marketing, 23(3): 342-355.

Silkes, C A, L A Cai, and X Y Lehto. (2013). "Marketing to the culinary tourist." Journal of Travel \& Tourism Marketing 30(4): 335-349.

Stone, M. J., Migacz, S., \& Wolf, E. (2018). Beyond the journey: the lasting impact of culinary tourism activities. Current Issues in Tourism. https://doi.org/10.10813683500.2018 .1427705$.

Susilaningsih, M. A., \& Yudhistira, B. (2017). Creativity From Soto: Toward A Soto Color Business In The Creative Economic Era. Proceeding Seminar Nasional 6th UNS SME Summit \& Awards, 194-202.

Tuan, L. Y., Jusoh, A., Mardani, A., \& Streimikiene, D. (2018). Restaurant Branding Matters: A Quantitative Report On How Brand Image Can Moderate Relationship. Journal of International Studies, 11(4): 270-282.

Wiyana, T., Putranto, T. S., Zukarnain, Arif., \& Kusdiana, R. N. (2018). City image towards tourist attraction (case in Solo, Central Java) examining city image of solo as tourist attraction. IOP Conference Series: Earth and Environmental Science 126 (IOP Publishing) 1-6.

Yasmin, P. A. (2018). Industri Makanan dan Minuman Tumbuh 9,23\%. Accessed on 23 April 2020, from https://finance.detik.com/industri/d-3985814/menperinindustri-makanan-dan-minuman-tumbub-923.

Tourism Research Journal, Volume 5 (1), 2021 